Journal of Economics and Behavioral Studies

Vol. 5, No. 10, pp. 718-729, Oct 2013 (ISSN: 2220-6140)

\title{
An Appraisal of the National Economic Empowerment and Development Strategy I (NEEDS I) in Nigeria: The Educational Perspective
}

\author{
Taiwo Aderemi \\ University of Ibadan, Nigeria \\ adekunte22@yahoo.com
}

\begin{abstract}
This paper set out to assess the performance of the National Economic Empowerment and Development Strategy (NEEDS I) in Nigeria in relation to its educational goals. These goals include; increasing enrolment in primary and secondary schools, improving the quality of education, and increasing funding to this critical sector. Several economic reform programmes in Nigeria have been abandoned not because they had no accomplishments, but largely as a result of paucity of studies assessing them. No paper in the Nigerian literature has appraised the NEEDS I vis-à-vis its stated educational objectives. This paper therefore fills this void. In realizing the objective of this study, I adopted the before and after approach, which involves comparing educational performance indicators before the initiation of the NEEDSI and during the programme. The findings revealed improved performance of educational indicators such as female enrolment in primary schools, adult literacy rate, primary school completion rate, and Senior Secondary School Certificate Examinations during the NEEDS programme, although achievements were modest. Budgetary allocation to the sector as a proportion of total budget was below 10 per cent and less than the 25 per cent UNESCO recommendation. Funding to this sector should be increased and monitored in order to achieve sustainable improvements in educational outcomes. Completion rate in secondary school was also low. This paper therefore suggests the extension of the universal basic education scheme to the senior secondary level to reduce drop-out rates.
\end{abstract}

Keywords: Needs, Enrolment, Literacy, Education

\section{Introduction}

The need to reduce poverty incidence has been a huge challenge facing the Nigerian government. Data from the World Bank quoted poverty incidence at $62.6 \%$ in 2010. Poverty in Nigeria is multi-faceted and manifests in joblessness, deprivation of basic needs of life, lack of access to credit, inability to exercise political rights amongst others (NPC 2004). In 1999, when the nation transitioned from a military regime to a democratic government, hopes of the masses were raised. There were indications that succor had come at last for the poor with the initiation of programmes such as the Poverty Alleviation Programme (PAP) and National Poverty Eradication Programme (NAPEP) in 2000 and 2001 correspondingly. The democratic government inherited an economy that had been bedeviled in moral, economic, socio, and political decadence. Poverty rate was 70 per cent, and the country was ranked by the Transparency International as the second most corrupt nation in the world ${ }^{1}$. Annual growth of per capita GDP (an indicator of economic development) was 1.3\%, compared to sub-Saharan Africa's and Ghana's $0.1 \%$ and $2.1 \%$ respectively (African Development Indicators 2007). Similarly educational performance indicators were on the down-side. The education sector was under-funded, adult literacy rate was $57 \%$, and primary school pupil-teacher ratio was high at 41:1. It therefore came as no surprise in 2004 when the Nigerian government launched the first phase of the National Economic Empowerment and Development Strategy (NEEDS) program. This short term policy lapsed in 2007, and second phase (NEEDS 2) was harmonized with the Seven-Point Agenda. The latter has as one of its goals, revitalization of the education sector. NEEDS was posed by the government as her poverty reduction strategy.

\footnotetext{
${ }^{1}$ See www.transparency.org/research/cpi/overview for explicit data on ranking of countries.
} 
The reform programme was different from other poverty alleviation programmes that had been embarked upon in the past, in that the planning process was highly participatory in nature (NPC 2004). The goals of NEEDS were poverty reduction, employment generation, wealth creation and value re-orientation. One of the thrusts of the reform was people empowerment which can be achieved through increased access to quality education. The role of human capital, particularly education in stimulating economic growth and development has been emphasized in the literature ${ }^{2}$. For instance, Vinod and Kaushik (2007) found that increase in literacy level drives gross domestic product in Nigeria. It is therefore surprising that no study in the Nigerian literature of which I am aware have assessed the performance of the NEEDS I programme in relation to its stated educational goals. This paper therefore fills this void. A study of this nature could provide policy input into addressing the shortcomings in the education sector and identify areas that needed urgent attention. This study therefore appraises the National Economic Empowerment and Development Strategy I in order to determine to what extent its stated educational objectives were achieved. The rest of the paper is structured as follows. The next section provides some background on the Nigerian education sector before the launching of NEEDS I in 2004. Section three gives a brief review of the assessment of NEEDS in Nigeria, while the methodology is presented in section four. Section five discusses the findings. Policy suggestions are proffered in section six.

\section{Background}

Figure 1: Education Expenditure as percentage of annual Budgets

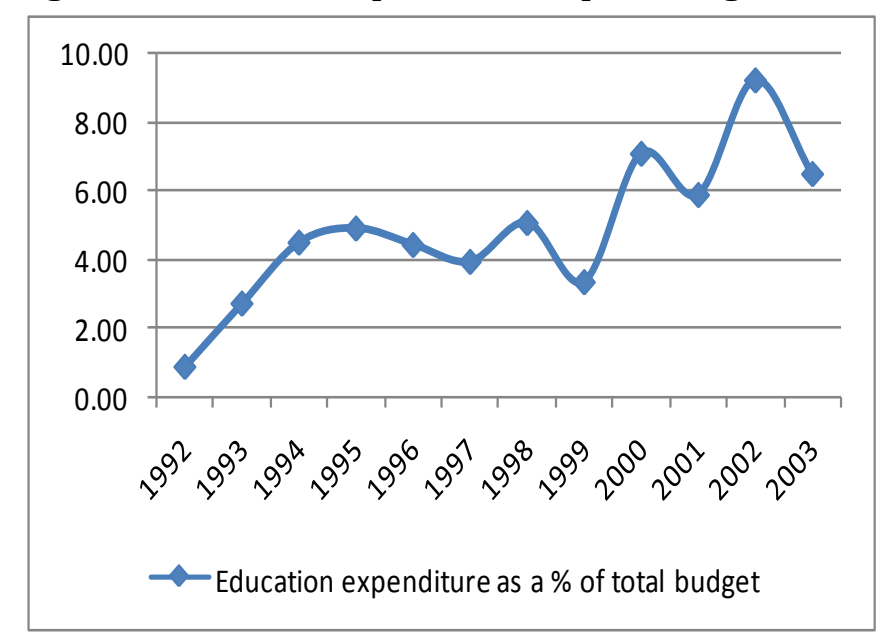

Source : Drawn using data from CBN Annual Report and Statement of Account of various years.

Figure 2: Adult Literacy Rate in Nigeria

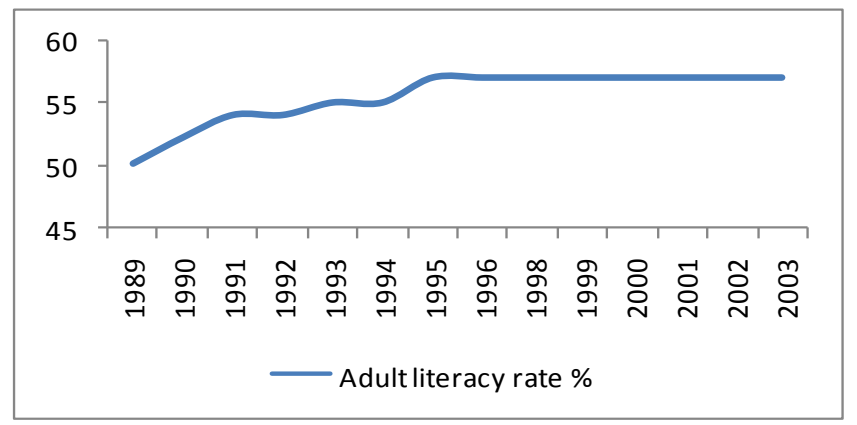

Source: Drawn using data from CBN Annual Report and Statement of Account of various years

${ }^{2}$ See Bloom et al. (2005) and Mahmood et al. (2012) for some of these studies. 
Table 1: Primary school pupil-teacher ratio

\begin{tabular}{ll}
\hline & Primary school pupil-teacher ratio \\
\hline 1989 & NA \\
1990 & 36 \\
1991 & 37 \\
1992 & 39 \\
1993 & 27 \\
1994 & 37 \\
1995 & 36 \\
1996 & 35 \\
1997 & 40 \\
1998 & 38 \\
1999 & 41 \\
2000 & 43 \\
2001 & 39 \\
2002 & 40 \\
2003 & 43 \\
Source: Economic and Social Statistics Bulletin (FOS) 1986, 1999, 2006
\end{tabular}

Figure 3: Contribution of Education sector to Nigeria's Real Gross Domestic Product

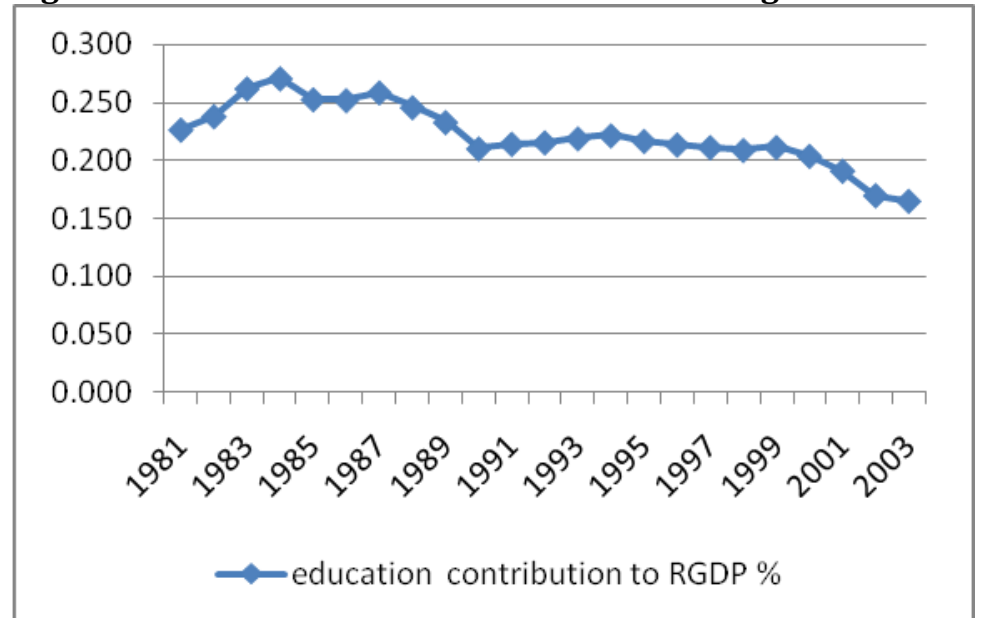

Source: Drawn by the author using data from CBN Statistical Bulletin (2011)

Figure 4: Primary School Enrolment Rate

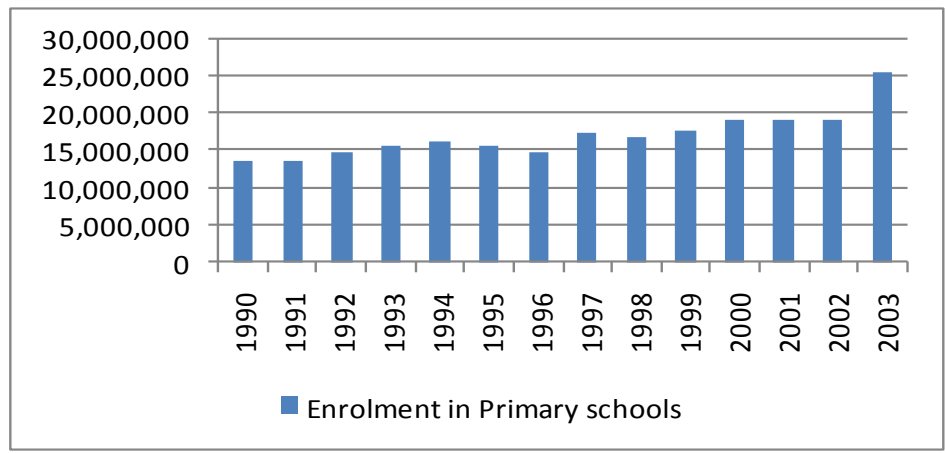

Source: Drawn using data from National Bureau of Statistics of various years

Figure 1 charts the total allocation to the education sector (capital and recurrent) as a proportion of the total budget in Nigeria between 1992 and 2003, before the launching of NEEDS I. Apparent is the steady rise in the trend of the education disbursement from 1992 to 1995, after which high instability manifested. The chart 
also shows that education expenditure reached a peak of $9.2 \%$ in 2002. This indicates that from 1992 to 2003, the United Nations Educational Scientific Organisation (UNESCO) requirement, which stipulated that developing countries should spend at least $25 \%$ of their annual budget on education, was not achieved. Figure 2 shows the adult literacy rate among people who are 15 years and above in Nigeria. From 1989 to 1995 there was a slow growth in the literacy rate. After 1995, a constant trend at 57\% was observed till 2003. This suggests that in 14 years, the adult literacy rate only grew by $6.9 \%$.

In Table 1, the pupil-teacher ratio is depicted. The pupil-teacher ratio which measures the quality of education and learning condition deteriorated between 1989 and 2003. In 1990, one teacher was available to 36 students in primary schools, while in 2003, it increased to 43 students. Figure 3 shows the continuous decline in the contribution of the education sector to the real gross domestic product. It fell from $0.23 \%$ in 1981 to $0.17 \%$ in 2003 . And it contributed an average of $0.22 \%$ in the period under observation. Enrolment in primary schools increased significantly by about $89 \%$ from $13,607,249$ in 1999 to $25,772,044$ in 2003 . The sharp increase in primary school enrolment can be attributed to the launching of the Universal Basic Education Act in 1999. ${ }^{3}$ It is apparent that between 1990 and 1998, enrolment increased by only 24.5\%, while it increased by about $44 \%$ between 1999 and 2003. Overall, the state of education as depicted by the educational indicators above suggests a poor performance before the inception of the NEEDS I programme. Nevertheless, it is too early to make relative comparisons with the performance during the NEEDS, as this is the major goal of this paper.

\section{Literature Review}

The literature on the assessment of the performance of the National Economic Empowerment and Development Strategy I in Nigeria is scanty. A large number of studies on the topic are discursive and only appraised its theoretical underpinning, and how realistic the targets are. However, few authors have used descriptive method to assess the reform programme. A plausible reason for the inadequate empirical literature on this topic is the brevity of the programme. This suggests a small sample size, thus making a comprehensive empirical study difficult. Since the goal of this study is to appraise the performance of NEEDS I, I shall focus more on studies that have used data to assess the performance of NEEDS I, and less on those that critiqued the framework of the reform. This is necessary in order to make comparison with the findings of this study. Falokun \& Adeoye (2006) examined the performance of NEEDS I with respect to its stated sectoral targets. They used data on sector contribution to the gross domestic product, employment generation, and other indicators. The authors argued that the reform did not increase the agriculture sector's contribution to economic growth as specified in the NEEDS I document. They also observed a decline in employment generation in this sector. Similarly, the target of increasing the annual growth in the manufacturing sector by $7 \%$ was not achieved. It was pointed out that NEEDS was unable to improve the potential linkages of the manufacturing sector in terms of its employment and export capabilities. One major goal of the NEEDS I, which was to diversify the productive base of the economy away from crude-oil was also not met. As argued by the authors, oil revenue still constituted $80 \%$ and $90 \%$ of revenue generated and exports respectively. However, the performance of the service sector improved, with its contribution to the GDP increasing from $11.2 \%$ in 2003 to $13.8 \%$ in 2004.

Adeyemo et al. (2008) challenged the ideological underpinning and framework of the NEEDS. According to them, the document did not clearly identify any ideology for achieving its stated development goals. They criticized the plan for failing to incorporate the lingering issue of inequality in the system and further imbalance in equity which the short term plan could arouse. Marcellus (2009) extended the literature by assessing the performance of the NEEDS in Nigeria between 2003 and 2007. Unlike the previous study, he used some data to support his arguments and concluded that the programme did not achieve more than past development plans in the country. Specifically, the author argued that the goals of poverty reduction, wealth creation, employment generation, and value-reorientation were not accomplished. More recently, Bambale (2011) evaluated the NEEDS I in relation to its poverty goals and utilized more data than Marcellus (2009). His assessment of the performance of NEEDS is mixed. On the upside, he argued that the average growth rate

${ }^{3}$ Under the UBE Act, primary education up to the junior secondary school is compulsory and free. 
recorded during the NEEDS surpassed its annual target of 6\%, foreign direct investment also increased, and substantial part of the nation's foreign debt was written-off. On the flip side, he argued that poverty incidence and living standard worsened during the reform. Two salient inferences are apparent from the reviewed literature. The first is that no comprehensive study has been done on the appraisal of the NEEDS I, particularly with respect to the education sector. Secondly, the existing findings are not explicit enough to reach a conclusion on the performance of the reform programme. Given this scarcity of evidence, some questions still remain for analysis. How did the education sector perform during the NEEDS I? Were the set goals of increasing school enrolment, raising adult literacy level, amongst others achieved? This paper provides answers to these questions.

\section{Methodology}

My approach follows the before and after comparison method and the actual versus target technique in assessing the performance of the education sector under the National Economic Empowerment and Development Strategy (NEEDS I). This technique was adopted by Ojo (1988) and Falokun \& Adeoye (2006). Specifically, this paper draws largely from 0jo (1988) in which the author used this method to appraise the Structural Adjustment Programme (SAP) in Nigeria in relation to the agriculture sector. The choice of this method is informed by the short duration of the NEEDS I programme, which makes it difficult for any meaningful empirical analysis to be carried out with such a small observation. The before and after technique compares variables of interest in the period before and after a reform. The actual-versus-target approach however compares actual programme performance key variables to the targets set in the programme. The success of the programme is then measured by the extent to which program targets are achieved. Along this line, I investigated the impact of NEEDS on the education sector in Nigeria using descriptive method. In doing this, the study examined the relevant educational performance indicators such as: total education expenditure, primary and secondary schools enrolment, gender-enrolment ratio, pupil-teacher ratio, adult literacy rate e.t.c. These indicators were examined critically with respect to NEEDS educational objectives which included increased education funding, increased enrolment in schools, especially among female students, and improvement in the quality of education. The data used were sourced from the Nigeria National Bureau of Statistics (NBS), Central Bank of Nigeria Statistical Bulletins and Annual Reports, and Statistical Information on Basic Education in Nigeria.

\section{Results and Discussion}

One major goal of the NEEDS was to reduce poverty. This was to be achieved through a set of macroeconomic framework which included people empowerment. Restructuring and investing in the Nigerian education sector is one way to empower people as highlighted in the NEEDS document. In this respect, I have analyzed the effects of NEEDS on the education sector by examining to what extent its stated objectives of increasing primary and secondary school enrolment, improving the quality of education, achieving adult literacy rate of 65 per cent by 2007, and increasing funding to the sector were achieved between 2004 and 2007. Table 2 shows the total disbursement to the education sector in Nigeria before the inception of NEEDS I and during the programme. One of the objectives of the reform was to restructure the education sector by increasing its budgetary allocation. Nominal education expenditure increased by 151\% between 1999 and 2003 (pre-NEEDS), while during the NEEDS it rose by 148\%. However, the worth of this allocation as reflected by the real education expenditure was marginal. Education expenditure increased by only $45.7 \%$ and $38.2 \%$ during pre-NEEDS and NEEDS period respectively. This clearly points to high inflation rate during the period. For instance, between 2000 and 2007, year-on-year inflation rate average 13\%. Figure 5 further shows the year-on-year growth rate of nominal education expenditure. The high volatility of the trend before the NEEDS is apparent. The growth rate declined sharply by $-27.4 \%$ in 2003 . With the initiation of NEEDS in 2004, the growth rate rebounded by $7.7 \%$ and continued on an upward smooth path till 2007 marking the end of the NEEDS programme. This growth trend was however not sustained in 2008, as education expenditure grew by only $7.7 \%$. 
Table 2: Federal Government Total Expenditure (Capital and Recurrent) on Education (1999-2008) Naira (Million)

\begin{tabular}{|c|c|c|c|c|c|c|c|}
\hline Year & $\begin{array}{l}\text { Total Expend on } \\
\text { education(nominal) }\end{array}$ & $\begin{array}{l}\text { Capital } \\
\text { expend } \\
\text { as a \% of } \\
\text { total } \\
\text { education } \\
\text { expend }\end{array}$ & $\begin{array}{l}\text { Recurrent } \\
\text { expend as } \\
\text { a \% of } \\
\text { total } \\
\text { education } \\
\text { expend }\end{array}$ & $\begin{array}{l}\text { Total } \\
\text { Expend } \\
\text { on } \\
\text { Education } \\
\text { (real) }\end{array}$ & $\begin{array}{l}\text { Total Education } \\
\text { expend as a \% } \\
\text { of Total Govt. } \\
\text { Expend }\end{array}$ & 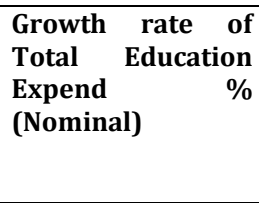 & $\begin{array}{l}\text { Growth rate of } \\
\text { Total Expend } \\
\text { \%(Real) }\end{array}$ \\
\hline 1999 & $31,563.8$ & 26.98 & 73.01 & $2,977.70$ & 3.33 & - & - \\
\hline 2000 & $49,563.2$ & 21.24 & 78.75 & $3,465.95$ & 7.07 & 57.0 & 16.4 \\
\hline 2001 & $59,744.6$ & 33.24 & 66.75 & $4,345.06$ & 5.87 & 20.5 & 25.4 \\
\hline 2002 & $109,455.2$ & 8.41 & 91.58 & $6,653.80$ & 9.21 & 83.2 & 53.1 \\
\hline 2003 & $79,436.1$ & 18.48 & 81.51 & $4,340.77$ & 6.48 & -27.4 & -34.8 \\
\hline 2004 & $85,580.8$ & 10.57 & 89.42 & $3,868.93$ & 6.18 & 7.7 & -10.9 \\
\hline 2005 & $114,737.9$ & 27.83 & 72.16 & $4,375.96$ & 6.58 & 34.1 & 13.1 \\
\hline 2006 & 151,700 & 21.55 & 78.44 & $4,831.21$ & 7.81 & 32.2 & 10.4 \\
\hline 2007 & 197,600 & 23.68 & 76.31 & $6,004.25$ & 8.41 & 30.3 & 24.3 \\
\hline 2008 & 212,800 & 22.93 & 77.06 & $5,626.65$ & 6.91 & 7.7 & -6.3 \\
\hline
\end{tabular}

Source: CBN Statistical Bulletin of various years. Figures computed by author

Figure 5: Growth Rate of Nominal Education Expenditure

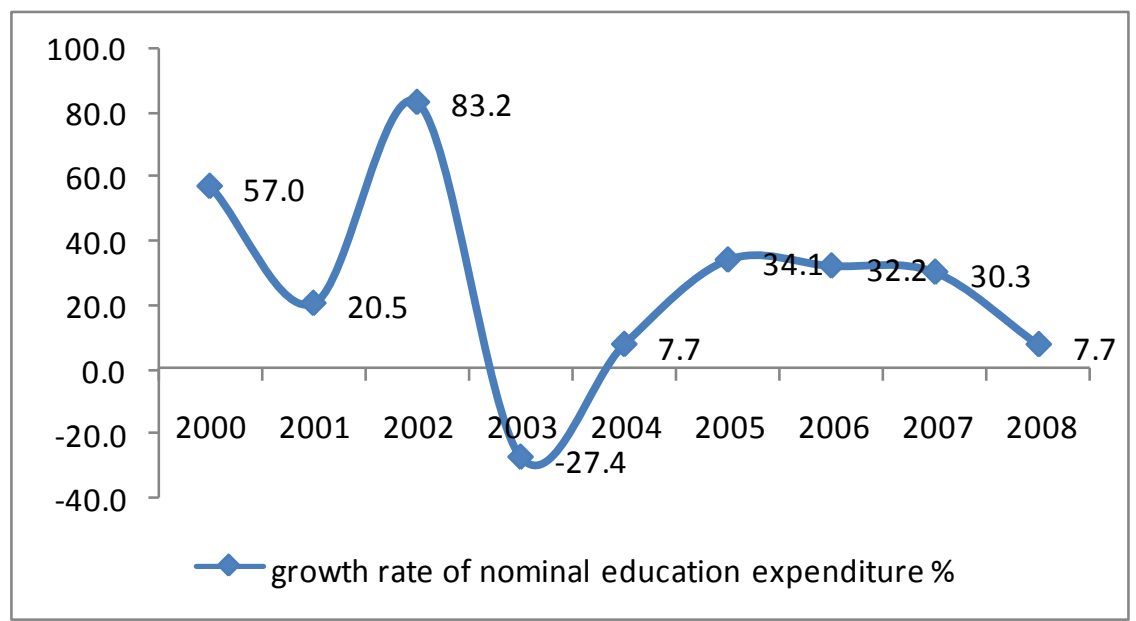

Source: Author's computation using table 2.

The capital and recurrent education expenditure component presented in table 2 reveals that the latter surpassed the former with wide margin between 1999 and 2008. In fact, in 2002 capital expenditure component was as low as $8.41 \%$ and did not exceed $34 \%$ all through. This pattern reflects a strong bias towards recurrent spending and shows that a greater proportion of the total education expenditure is incurred on personnel and overhead cost. It is clear that the government has been spending a smaller proportion of education expenditure on capital expenditure and this explains why the educational institutions and their facilities are in a state of disrepair and neglect. Further analysis indicates that during the NEEDS some improvement was recorded over the pre-NEEDS period, as the share of capital education 
expenditure increased from $18.48 \%$ in 2003 to $23.68 \%$ in 2007. In the pre-NEEDS period, capital expenditure component declined from $26.98 \%$ in 1999 to $18.48 \%$ in 2003. Nevertheless, this marginal increase in the share of capital education during the NEEDS period may not have been sufficient to ensure that the NEEDS I target of guaranteeing that $50 \%$ and $60 \%$ of primary and secondary schools respectively have conducive learning environments.

It is apparent that when it appears that nominal allocations to the education sector have increased substantially over the years, the relative weight of these allocations was low. This is shown by the total education expenditure as a percentage of total government expenditure, in table 2 . We would note that it ranged between $3.33 \%$ and $9.21 \%$. It has been much lower than the 25 percent recommended by the United Nations Educational Scientific Organization (UNESCO). Education expenditure as a percentage of total government expenditure in pre-NEEDS period average 6.3\%, compared to 7.2\% in NEEDS period. The trend of education expenditure as a percentage of total budget was unstable in the pre-NEEDS period as shown in table 2. In the NEEDS period, a rising trend was observed from $6.1 \%$ in 2004 to $8.41 \%$ in 2007 . It however declined to $6.9 \%$ in 2008 .

Figure 6: Primary school enrolment in Nigeria

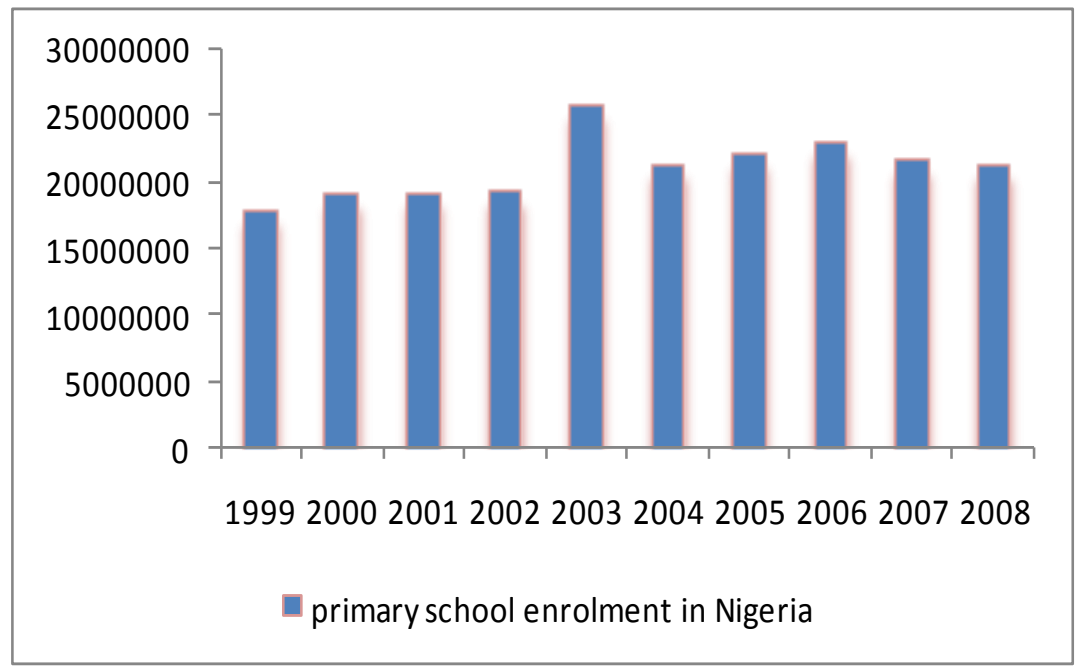

Table 3: Indicators of the State Of Education in Primary Schools in Nigeria

\begin{tabular}{lllllll}
\hline Year & $\begin{array}{l}\text { Pry. School } \\
\text { Enrolment }\end{array}$ & $\begin{array}{l}\text { Change } \\
\text { over } \\
\text { preceeding } \\
\text { year\% }\end{array}$ & $\begin{array}{l}\text { No } \\
\text { Pupils } \\
\text { per } \\
\text { Teacher }\end{array}$ & $\begin{array}{l}\text { \% } \\
\text { Female } \\
\text { student }\end{array}$ & $\begin{array}{l}\text { of } \\
\text { Primary } \\
\text { school } \\
\text { Gender } \\
\text { ratio \% }\end{array}$ & $\begin{array}{l}\text { Pry. Six completion } \\
\text { rate \% }\end{array}$ \\
\hline 1999 & $17,907,008$ & - & 41 & NA & NA & 72.9 \\
2000 & $19,100,000$ & 6.7 & 43 & 44.0 & 78.5 & 76.7 \\
2001 & $19,264,000$ & 0.9 & 39 & 43.9 & 78.2 & 83.4 \\
2002 & $19,353,000$ & 0.5 & 40 & 45.4 & 83.1 & 85.1 \\
2003 & $25,772,044$ & 33.2 & 43 & 43.9 & 78.2 & 91 \\
2004 & $21,395,510$ & -17 & 36 & 44.7 & 80.8 & 93.1 \\
2005 & $22,115,432$ & 3.4 & 37 & 44.9 & 81.4 & 92.4 \\
2006 & $23,017,124$ & 4.1 & 39 & 45.4 & 83.1 & 92.43 \\
2007 & $21,632,070$ & -6.0 & 46 & 46 & 85.1 & 95.3 \\
2008 & $21,294,518$ & -1.6 & 36 & 46.1 & 85.5 & 92 \\
\hline
\end{tabular}

Handbook of Information on Basic Education in Nigeria, National Bureau of Statistics, Federal Ministry of Education, Annual abstract of statistics, Nigeria Gender statistics book. Computations by the Author

Figure 6 and table 3 both show a slow, but rising trend in primary school enrolment in Nigeria. Enrolment increased marginally by 19\% between 1999 and 2008, with an average growth rate of just 2.6\%. Declines in 
enrolment were recorded in 2004, 2007, and 2008. Enrolment in the pre-NEEDS and NEEDS period increased by $43 \%$ and $1.1 \%$ correspondingly. Increased enrolment in the pre-NEEDS period can be attributed to the launching of the Universal Basic Education in 1999, which provided free education at the primary school level up to the junior high school. The modest increase in enrolment could be partly explained by low enrolment in some States which may have contributed in slowing down the national growth rate of primary school enrolment. Table 4 presents enrolment in primary school in Abia, Kano and Oyo states representing the Eastern, Northern, and Western part of Nigeria respectively. Between 1999 and 2008, primary school enrolment in Abia-state declined by 56.4\%, female enrolment dominated except in 2004 and 2005, and primary six completion rate dropped by almost half. This trend is not unexpected as men in the Eastern states of Nigeria are known to give more priority to business activities than education. In addition male children are introduced in their childhood years to business, thus leading to high drop-out rates. In the West, proxied by Oyo-state, enrolment increased by $15.7 \%$, primary six completion rate rose significantly and female enrolment equally matched with male. Enrolment also increased in Kano-state. Nevertheless, primary six completion rate declined and male enrolment dominated female in all the years under observation. This trend can be attributed to the pronounced religious bias against the education of women in this region. Overall, primary school enrolment in Oyo and Kano states increased by $15.7 \%$ and $45.2 \%$ respectively, while it declined by 56.4\% in Abia state between 1999 and 2008.

Table 4: Enrolments by gender, and completion of primary six in Abia, Oyo, and Kano States

\begin{tabular}{llllllll}
\hline State & Year & $\begin{array}{l}\text { No of } \\
\text { completing pry six }\end{array}$ & $\begin{array}{l}\text { Total } \\
\text { M }\end{array}$ & $\begin{array}{c}\text { Enrolment } \\
\text { F }\end{array}$ & Pry 1-6 & Total & \% Female \\
\hline ABIA & 1999 & 102,275 & 336,954 & 340,284 & 677,238 & 50.2 \\
& & & 324,995 & 328,478 & 653,473 & 50.2 \\
& 2000 & 97,939 & 362,442 & 369,169 & 731,611 & 50.4 \\
& 2001 & 107,658 & 333,467 & 338,128 & 671,595 & 50.3 \\
& 2002 & 100,998 & 138,165 & 139,278 & 277,443 & 50.2 \\
& 2003 & 42,176 & 196,762 & 191,175 & 387,937 & 49.3 \\
& 2004 & 67,849 & & & & \\
& & 202,515 & 192,871 & & 48.8 \\
& & & & & 395,386 & \\
& 2005 & 61,400 & 119,272 & 120,415 & 239,687 & 50.2 \\
& & 133,220 & 133,737 & 266,957 & 50.1 \\
& 2006 & 53,212 & 55,015 & 143,096 & 152,055 & 295,151 & 51.5 \\
\hline
\end{tabular}

\begin{tabular}{llllllll}
\hline State & Year & $\begin{array}{l}\text { No of } \\
\text { completing pry six }\end{array}$ & $\begin{array}{l}\text { Pupils } \\
\text { M }\end{array}$ & Fotal Enrolment & Pry 1-6 & Total & \% \\
\hline OYO & 1999 & 112,800 & 399,175 & & & Female \\
& 2000 & 116,077 & 404,474 & 491,430 & 790,605 & 49.5 \\
& 2001 & 98,412 & 350,791 & 351,832 & 809,896 & 50.0 \\
& 2002 & 111,747 & 388,417 & 385,986 & 774,403 & 49.8 \\
& 2003 & 146,327 & 498,840 & 499,448 & 998,288 & 50.0 \\
& 2004 & 124,010 & 414,864 & 416,475 & 831339 & 50.1 \\
& 2005 & 137,222 & 437,852 & 444,565 & 882,417 & 50.4 \\
& 2006 & 151,000 & 458,274 & 468,129 & 926,403 & 50.5 \\
& 2007 & 182,481 & 528,485 & 542,148 & $1,070,633$ & 50.6 \\
& 2008 & 150,120 & 450,123 & 464,769 & 914,892 & 50.8 \\
\hline
\end{tabular}




\begin{tabular}{|c|c|c|c|c|c|c|}
\hline State & Year & $\begin{array}{l}\text { No of Pupils } \\
\text { completing pry six }\end{array}$ & $\begin{array}{ll}\text { Total } & \text { Enrolment } \\
\text { M } & \text { F }\end{array}$ & Pry 1-6 & Total & $\%$ Female \\
\hline & & 1 & & & & \\
\hline \multicolumn{7}{|l|}{ KANO } \\
\hline & 1999 & 62,741 & 706,628 & 476,376 & $1,183,004$ & 40.2 \\
\hline & 2000 & 169,464 & 779,116 & 503,984 & $1,283,100$ & 39.2 \\
\hline & 2001 & 146,104 & 603,189 & 461,165 & $1,064,354$ & 43.3 \\
\hline & 2002 & 154,809 & 737,507 & 501,794 & $1,239,301$ & 40.4 \\
\hline & 2003 & 191,277 & $1,036,483$ & 727,624 & $1,764,107$ & 41.2 \\
\hline & 2004 & 143,993 & 767,996 & 561,472 & $1,329,468$ & 42.2 \\
\hline & 2005 & 151,000 & 796,520 & 598,036 & $1,394,556$ & 42.9 \\
\hline & 2006 & 154,242 & 965,244 & 774,248 & $1,739,492$ & 44.5 \\
\hline & 2007 & 156,184 & 832,002 & 678,442 & $1,510,444$ & 44.9 \\
\hline & 2008 & 155,200 & 956,155 & 761,806 & $1,717,961$ & 44.3 \\
\hline
\end{tabular}

Source: Compiled by the author from statistical information on Basic Education in Nigeria of various years, and the Nigerian Bureau of Statistics

Caution should be exercised when interpreting a rising school enrolment rate. This is because; getting children to school is one thing, keeping them there is another. Many children drop-out before they complete their primary school education. Table 3 therefore presents primary six completion rates. In the pre-NEEDS period, completion rate average $81.8 \%$. This increased to an average of $93.3 \%$ during NEEDS I programme. At the expiration of the NEEDS I programme in 2007, primary six completion rate of $95.3 \%$ in Nigeria compared favourably with its peers. For instance in Ghana completion rate was 83.9\% in 2007 (Ghana Ministry of Education 2009). Overall, primary school completion rate in Nigeria between 1999 and 2008 averaged $87.4 \%$. Leading the agenda of NEEDS I was the objective to increase female enrolment in schools. Table 3 further shows that in the pre-NEEDS period, female enrolment in primary schools average $44.3 \%$. It however increased marginally to an average of $45.3 \%$ in the NEEDS period. Similarly, the gender ratio which reflects the balance in male-female enrolment stood at $85.1 \%$ at the end of the NEEDS programme in 2007. A gender ratio of $100 \%$ indicates parity in male-female enrolment.

Table 5: INDICATORS OF THE STATE OF EDUCATION IN POST-PRIMARY SCHOOLS IN NIGERIA

\begin{tabular}{|c|c|c|c|c|c|c|c|c|}
\hline Year & $\begin{array}{l}\text { Enrolment } \\
\text { in post- } \\
\text { primary } \\
\text { schools }\end{array}$ & $\begin{array}{l}\text { change } \\
\text { over } \\
\text { preceeding } \\
\text { year\% }\end{array}$ & $\begin{array}{l}\text { No of } \\
\text { pupils } \\
\text { per } \\
\text { teacher }\end{array}$ & $\begin{array}{l}\text { \% of } \\
\text { female } \\
\text { students }\end{array}$ & $\begin{array}{l}\text { No of pupils } \\
\text { Completing } \\
\text { SSS3 }\end{array}$ & $\begin{array}{l}\text { Males } \\
\text { completing } \\
\text { SSS3 }\end{array}$ & $\begin{array}{l}\text { Females } \\
\text { completing } \\
\text { SSS3 }\end{array}$ & $\begin{array}{l}\text { SSS } 3 \\
\text { Completion } \\
\text { rate \% }\end{array}$ \\
\hline 1999 & $3,844,585$ & & 38 & 45 & 511,328 & 281,689 & 229,639 & 23.5 \\
\hline 2000 & $4,104,345$ & 6.8 & 31 & 46 & 571,089 & 313,009 & 258,080 & 24.0 \\
\hline 2001 & $4,601,000$ & 12.1 & 32 & 47 & 622,248 & 346,057 & 277,191 & 25.1 \\
\hline 2002 & $4,866,000$ & 5.8 & 30 & 48 & 653,079 & 360,971 & 292,108 & 25.3 \\
\hline 2003 & $6,152,000$ & 26.4 & 34 & 42 & 818,572 & 458,343 & 360,229 & 30.4 \\
\hline 2004 & $6,279,462$ & 2.1 & 40 & 43 & 821,290 & 465,200 & 356,090 & 33.2 \\
\hline 2005 & $6,397,343$ & 1.9 & 44 & 44 & 843,520 & 463,963 & 379,584 & 33.8 \\
\hline 2006 & $6,536,038$ & 2.2 & 32 & 44.2 & 854,000 & 478,240 & 375,760 & 41.2 \\
\hline 2007 & $6,068,160$ & -7.2 & 29 & 42.9 & 860,310 & 481,220 & 379,090 & 42.6 \\
\hline 2008 & $6,625,943$ & 9.2 & 24 & 44.4 & 869,708 & 490,450 & 379,258 & 43.1 \\
\hline
\end{tabular}

Source: Statistical information on Basic Education in Nigeria of various years, Annual Abstract of Statistics of various years SSS3 completion rate was computed by the author using school age 16.

Table 3 also shows the number of pupils per teacher which is an indicator of access to learning and quality of education. The greater the number of students per teacher the lower the access to learning facilities. Overall, pupil-teacher ratio declined from 41 in 1999 to 36 in 2008, which indicates an improvement in learning. Prior to the implementation of the NEEDS programme, pupil-teacher ratio was above 40 between 1999 and 2003, except in 2001, when it declined to 39. During the NEEDS however, the ratio was well below 40, except in 2007, when it increased to 46. In addition, in the NEEDS period, the pupil-teacher ratio average 39.5, 
compared to 41.2 in pre-NEEDS period. In Ghana, pupil-teacher ratio was 33.5 between 2004 and 2007. As shown in table 5, enrolment in post-primary schools increased by $72 \%$ between 1999 and 2008. A careful comparison of enrolments before the NEEDS programme and during the programme indicates an average growth of $12.7 \%$ and $-0.3 \%$ in that order. This poor growth rate in post-primary school enrolment during the NEEDS programme could be as a result of the re-introduction of school-fees and Senior Secondary School Certificate Examination (SSSCE) fees in some states in Nigeria during the period. The male-female enrolment trend shows that male enrolment dominated female enrolment in all the years under review. Female enrolment rose from $45 \%$ in 1999 to $48 \%$ in 2002, but declined sharply to $42 \%$ in 2003 . However, with the launching of the NEEDS programme in 2004, female enrolment increased gradually, although declined marginally in 2007.

\section{Table 6: Students performance in Senior Secondary School Certificate Examination (SSSCE)}

\begin{tabular}{|c|c|c|c|c|c|c|}
\hline \multicolumn{7}{|l|}{ Year } \\
\hline & \multicolumn{3}{|c|}{ English Language } & \multicolumn{2}{|c|}{ Mathematics } & \\
\hline & $\begin{array}{l}\text { Total No of } \\
\text { Students who } \\
\text { sat for } \\
\text { English }\end{array}$ & $\begin{array}{l}\% \text { credit } \\
\text { pass }\end{array}$ & $\begin{array}{l}\text { no of students } \\
\text { that passed }\end{array}$ & $\begin{array}{l}\text { Total No of } \\
\text { Students who sat } \\
\text { for Mathematics }\end{array}$ & \% credit pass & $\begin{array}{l}\text { no of } \\
\text { students } \\
\text { that passed }\end{array}$ \\
\hline 1999 & 757,233 & 9.71 & 73,527 & 756,680 & 18.25 & 138,094 \\
\hline 2000 & 636,064 & 10.82 & 68,822 & 643,371 & 32.81 & 211,090 \\
\hline 2001 & $1,040,101$ & 26.07 & 271,154 & $1,023,102$ & 36.55 & 373,943 \\
\hline 2002 & 925,289 & 24.57 & 227,343 & $1,078,901$ & 34.50 & 372,220 \\
\hline 2003 & 939,507 & 29.03 & 272,738 & 939,506 & 36.91 & 346,771 \\
\hline 2004 & $1,020,431$ & 29.59 & 301,980 & $1,019,524$ & 33.97 & 346,410 \\
\hline 2005 & $1,064,587$ & 25.63 & 272,922 & $1,054,853$ & 38.2 & 402,982 \\
\hline 2006 & $1,154,266$ & 32.48 & 375,007 & $1,149,277$ & 41.12 & 472,674 \\
\hline 2007 & $1,252,570$ & 30.32 & 379,831 & $1,249,028$ & 46.75 & 584,024 \\
\hline 2008 & $1,348,214$ & 34.90 & 470,635 & $1,340,907$ & 57.24 & 767,596 \\
\hline
\end{tabular}

Source: Computed by the author from the National Bureau of Statistics, various years.

Notes: A credit pass in both Mathematics and English Language is required for entry into higher institutions of learning in Nigeria.

Despite the high overall post-primary school enrolment between 1999 and 2008, completion rate was very low. It average $32.2 \%$. Similarly, in the pre-NEEDS and during the NEEDS programme, completion rates were $26 \%$ and $38 \%$ respectively. A major inference that can be drawn from this is that despite the modest increase in enrolment, drop-out rate was very high. Comparing primary school with post-primary school completion rates, the data shows a higher rate of completion of primary education. For instance between 1999 and 2008 completion rates in primary and post-primary schools were $87.4 \%$ and $32.2 \%$ correspondingly. High completion rate in the primary schools could be largely explained by the free basic education in primary schools. This free basic education does not extend to the senior secondary level. However, cost of education is high at this level of education and students often drop-out to engage in activities that will supplement family income. Also, between 1999 and 2008, males completing SSS3 dominated the female. This may be traced to the fact that since educational cost at this level is not free and also expensive, female students drop-out either to assist with family businesses or farm. Also they are married-off at this age or leave school because of teenage pregnancy (UNICEF 2007). Access to learning in post-primary schools as shown by the pupil-teacher ratio in table 5 improved in the NEEDS and pre-NEEDS period by $14.7 \%$ and $10.5 \%$ respectively. Teacherpupil ratio of 29 was achieved in 2007 at the termination of the NEEDS I programme. This was a major improvement over the pupil-teacher ratio of 38 in 1999. The performances of secondary school students in the senior secondary school certificate examinations (SSSCE) between 1999 and 2008 is presented in table 6 .This is used to proxy the quality of education in secondary schools in Nigeria.

The performance of students in the two core subjects; Mathematics and English-Language are examined. A careful look at table 6 shows an overall poor performance in English Language, although there were some improvements over the years. In 1999, only $9.7 \%$ of those who registered for English-Language passed, while the figure increased to a peak of $34.9 \%$ in 2008 . An intuition that can be drawn from this is that, barring other 
effects, each year at least $65 \%$ of these students did not gain admission into universities. This is because a credit pass in English-Language is required for entry into the university, In the pre-NEEDS period, average credit pass was $20 \%$ compared to $30 \%$ during NEEDS programme. This poor trend was mirrored in Mathematics, another core subject. However, there was a slight improvement in the performance over English language in the review period. Only $18.2 \%$ of students who sat for mathematics passed in 1999. In 2008 the statistic rose to $57 \%$. Similarly, in the pre-NEEDS period, $31.8 \%$ passed, while during the NEEDS period, it increased to $40 \%$. The modest improvement in the performances of students in both subjects during the NEEDS I period reflects the educational accomplishments recorded in the NEEDS I programme. Table 7 shows that the adult literacy rate in Nigeria increased from $57 \%$ to $66 \%$ in 2008. Pre-NEEDS period was marked with no improvement in the adult literacy rate. However, during the NEEDS period, adult literacy rate increased from 57\% in 2003 to $69.3 \%$ in 2007. In addition, NEEDS I target of increasing adult literacy rate to $65 \%$ by 2007 was surpassed.

Table 7: Adult Literacy Rate in Nigeria (1999-2008)

\begin{tabular}{ll}
\hline Year & Adult Literacy Rate \\
\hline 1999 & 57.0 \\
2000 & 57.0 \\
2001 & 57.0 \\
2002 & 57.0 \\
2003 & 57.0 \\
2004 & 62.37 \\
2005 & 63.1 \\
2006 & 62.37 \\
2007 & 69.3 \\
2008 & 66 \\
\hline
\end{tabular}

Source: CBN Annual Report 2001, 2004 and Annual Abstract of Statistics 2009

\section{Conclusion and Policy Suggestions}

The performance of the education sector in Nigeria during the National Economic Empowerment and Development Strategy I (NEEDS I) as indicated by the educational indicators suggest modest improvement over pre-NEEDS years. Although funds earmarked to the education sector did not increase much, a sustained steady and rising growth rate was apparent during the NEEDS I period. Another accomplishment during NEEDS I was the observed gradual increase and decline in the capital and recurrent expenditure component respectively. This indicated increased spending on the dilapidated physical structures and other capital educational inputs. Primary schools are still characterized by low enrolments, although completion rate is high. Increasing number of female students is also enrolling. The quality of education in primary schools as suggested by the average pupil-teacher ratio is on the upside. In secondary schools, despite the increase in enrolments, completion rate is still low, although some improvements were recorded during the NEEDS programme. Performances of students in the Senior Secondary School Certificate Examinations also improved during the NEEDS programme, albeit modestly.

Based on these findings, it is suggested that educational spending need to be increased substantially in order to achieve greater educational outcomes. Simultaneously, misappropriation of these funds should also be checked and minimized. Efforts should also be made to keep students in schools and curb drop-out rates, particularly at the secondary level. One way of achieving this is to extend the free universal basic education scheme to the senior secondary levels. Apart from the extension of the free universal basic Act, other factors that are known to aid drop-out rates such as lack of educational accessories including uniforms, shoes and proximity of schools to villages should be addressed. Scholarships for girls should be provided to ease the burden of educational financing on parents in order increase girls' enrolments in the Northern part of Nigeria, where there is a high bias toward female-child education. Similarly, strategies to keep male students in school in the Eastern Nigeria should be adopted. By doing this, a balanced school enrolment and completion rates are achieved in all the geo-political zones in the country. The Child Rights Act adopted by Nigeria in 2003 should be enforced and strict penalties imposed on those who still engage children in child labour activities. 


\section{References}

Adeyemo, D., Salami, A. \& Adeyemi, L. (2008). An Appraisal of Economic Reforms in Nigeria. Contemporary Management Research, 4(2), 119-136.

African Development Indicators. (2007).The World Bank.

Bambale, A. (2011). NEEDS and Poverty Reduction in Nigeria: A Critique. Economics and Finance Review, 1(1), $15-24$.

Bloom, D., Canning, D. \& Chan, K. (2005). Higher Education and Economic Development in Africa. Manuscript, Harvard University.

Central Bank of Nigeria- CBN. (2000, 2001 2002, 2004, 2006). Annual Report and Statement of Account. CBN, Abuja

Central Bank of Nigeria-CBN. (2002, 2007, 2011). Statistical Bulletin. CBN, Abuja

Falokun, G. O. \& Adeoye, B. W. (2006). NEEDS Sectoral Target: A Consistency Analysis. A Paper Submitted to Broad-Based Roundtable on Partnership for Enhanced Success of NEEDS, Reiz Continental Hotel, Plot 779, Cadastral Zone AO, Central Area, Abuja, Organized by The Centre for Public-Private Cooperation, Ibadan, May 4-5, 2006.

Federal Office of Statistics- FOS. (1999). Economic and Social Statistics Bulletin, FOS Lagos.

Federal Office of Statistics- FOS. (1994). Social Statistics in Nigeria, FOS, Abuja

Marcellus, I. O. (2009). Development Planning in Nigeria: Reflections on the NEEDS (2003-2007). Journal of Social Science, 20(3), 197-201.

Mahmood, M. T. \& Rehman, K. (2012). Does Human Capital Expedite Economic Development? The Case of Pakistan. Journal of Economics and Behavioural Studies, 4(3), 163-171.

Ministry of Education, Ghana: www.moe.gov.gh/moe/sites/resources/stats.php

Ministry of Education, Republic of Ghana. (2009). Report on Basic Statistics and Planning Parameters for Basic Education in Ghana.

National Planning Commission. (2004). National Economic Empowerment and Development Strategy I, Abuja (NEEDS I).

National Bureau of Statistics-NBS. (1997, 1995, 2001, and 2009). Annual Abstract of Statistics, Abuja.

Ojo, M. O. (1988). Agricultural Performance and Policy under the Structural Adjustment Programme in Nigeria. Seminar Presentation at 1988 Annual Conference of the Nigerian Economic Society.

Transparency International: www.transparency.org/research/cpi/overview

UNICEF. (2007). Information Factsheet on Girls' Education. Nigeria Country Office, September 2007.

Vinod, H. D. \& Kausik, S. K. (2007). Human Capital and Economic Growth: Evidence from Developing Countries. The American Economist, 51(1), 29-39. 